\title{
Predicting the potential threat of Casuarina equisetifolia to three endemic plant species on the Turks and Caicos Islands
}

\author{
Chloe J. Hardman, Sophie Williams, Bryan Naqui Manco and \\ Martin A. Hamilton
}

\begin{abstract}
Invasive species are one of the main threats to the loss of global biodiversity. Controlling such species requires a high input of effort and resources and therefore it is important to focus control on areas that will maximize gains for conservation. We present a spatial modelling approach that will help target control efforts. We used presence-only data to develop habitat suitability models for the invasive tree Casuarina equisetifolia and three endemic plant species on the Turks and Caicos Islands in the Caribbean. Substantial overlap was found between suitable areas for the endemics and C.equisetifolia. Evidence for the potential harm that $C$. equisetifolia could cause to native vegetation was assessed using paired areas with and without invasion. Areas with C. equisetifolia present had lower native plant species richness than areas where it was absent, which suggests a negative effect of invasion on the growth of native plants. No endemic plants were found in areas where C. equisetifolia was present. Based on the data collected we recommend that the three endemic species be categorized as Endangered on the IUCN Red List. By highlighting areas where the endemic plants are found and demonstrating a potential threat to these habitats, we provide a plan for the designation of six Important Plant Areas to promote conservation of these endemic species.
\end{abstract}

Keywords Caribbean, Casuarina equisetifolia, endemic, Important Plant Areas, invasive species, MaxEnt, Turks and Caicos Islands

\section{Introduction}

The Caribbean region is recognized as a global bio1 diversity hotspot (Myers et al., 2000) and the Turks and Caicos Islands are regionally notable for large areas of wild

Chloe J. Hardman† (Corresponding author), Sophie Williams and Martin A. Hamilton Royal Botanic Gardens, Kew, Richmond, Surrey. E-mail chloehardman@gmail.com

Bryan NaqQi Manco Department of Environment and Coastal Resources, National Environmental Centre, Providenciales, Turks and Caicos Islands

†Current address: Centre for Agri-Environment Research, University of Reading, Reading, RG6 6AR, UK

Received 7 September 2010. Revision requested 14 December 2010.

Accepted 31 January 2011. First published online 3o March 2012. nature. However the high conservation value flora and fauna are increasingly threatened by development for the tourist industry and the spread of invasive species (Ray et al., 1999; Kairo et al., 2003; Garland-Campbell, 2008). This habitat change is of particular concern because the Islands are home to a number of endemic species, including nine plants. Here we focus on three of these endemic plant species for which unambiguous identification in the field is available.

The invasive tree Casuarina equisetifolia L. (Casuarinaceae) has spread rapidly in Turks and Caicos, most notably in the last 50 years (C. Forbes, pers. comm.) but there are few data on its range and impact on the Islands. C. equisetifolia is a dicotyledonous tree $7-25 \mathrm{~m}$ tall with wind-pollinated small brown flowers and seeds that are wind and water dispersed (Parrotta, 1993; Weber, 2003); it is one of the 100 worst invasive species (GISD, 2009). It is native to Australia, Oceania, Malaysia and southern Asia (Masterson, 2007) and was introduced into Barbados in c. 1870 (Elfers, 1988) and Florida in 1898 (Masterson, 2007) for coastal landscaping and as a windbreak. It probably reached the Turks and Caicos Islands at a similar time. C. equisetifolia is still planted on the Islands for landscaping, shade and sand stabilization. Awareness of its exotic status and negative impacts is low amongst local residents (Hardman, 2009). In Florida it is listed as a Category 1 exotic species (having damaging effects on the native ecosystem) and control programmes have been implemented (Langeland \& Burks, 1998). However empirical evidence of the negative impact of invasive plants is often lacking (Foxcroft \& Freitag-Ronaldson, 2007) and this is the case for C. equisetifolia.

Target 5 of the Global Strategy for Plant Conservation is to identify and protect a global network of key sites for plant conservation (Secretariat of the CBD, 2010). The research reported here contributes to this Strategy by providing data for the identification of Important Plant Areas (IPAs) on the Turks and Caicos Islands. The IPA initiative, led by Plantlife International, aims to identify and conserve areas of exceptional botanical importance (Plantlife International, 2006). The Strategy also calls for a preliminary assessment of the conservation status of all known plant species by 2010 (Secretariat of the CBD, 2010), and we contribute to this here by assessing the conservation status of three plants endemic to Turks and Caicos. 
Here we map the range of the three focal endemic plant species and assess their conservation status, compare the native vegetation of areas invaded and uninvaded by C. equisetifolia, and predict areas of habitat suitable for the three endemic species and for C. equisetifolia. We use these data to recommend the designation of six IPAs.

\section{Study area}

The Turks and Caicos Islands are a UK Overseas Territory in the northern Caribbean (Fig. 1). The total land area of the archipelago is $430 \mathrm{~km}^{2}$. Biogeographically the Islands are contiguous with the Bahama archipelago. Nine of the 40 islands are permanently inhabited and two are being developed to have permanent settlements. The Islands are predominantly low-lying limestone and vegetation is largely secondary, on old plantation sites (Mills, 2008). Natural disturbances include fires and hurricanes. Dunes and limestone scrub are the most prevalent habitats but there are also areas of dry tropical forest, pine rocklands (locally called pineyards) and salinas (brackish, periodically inundated pools). The major threats to the natural habitats of the Islands are conversion for development, mostly associated with the tourist industry, and the threat of rising sea levels associated with climate change (Ray et al., 1999).

\section{Endemic plant species profiles}

Argythamnia argentea Millsp. (Euphorbiaceae) is a monoecious shrub that can reach $60 \mathrm{~cm}$ but usually grows close to the ground. Three other, non-endemic, species of Argythamnia occur on the Islands and are superficially similar in appearance to A. argentea (Correll \& Correll, 1982). The entire leaves of $A$. argentea are alternate and their thick silvery pubescence is a distinguishing feature (Correll \& Correll, 1982). Pollination method is unknown. Seed dispersal is by elastically dehiscent fruit capsules (BNM, pers. obs.). The species is abundant on Big Ambergris Cay (MAH, pers. obs.) and has been documented on Grand Turk (Correll \& Correll, 1982).

Encyclia caicensis Sauleda and Adams (Orchidaceae) has erect, linear leaves up to $60 \mathrm{~cm}$ long and $4 \mathrm{~cm}$ wide, and elongated, clustered pseudobulbs up to $15 \mathrm{~cm}$ in length and $5 \mathrm{~cm}$ in diameter (BNM, pers. obs.). The species occurs both as an epiphyte and as a terrestrial plant on coastal dunes. The terminal inflorescence grows up to $215 \mathrm{~cm}$, with closely spaced branches and internodes. The three lobed, whiteyellow labellum has distinct red-purple stripes (Correll \& Correll, 1982). Seed capsules are pendant and up to $3 \mathrm{~cm}$ long. The plant retains the old flowering stems, making identification of the species, based on internode spacing and position of inflorescence branches, easier (BNM, pers. obs.).

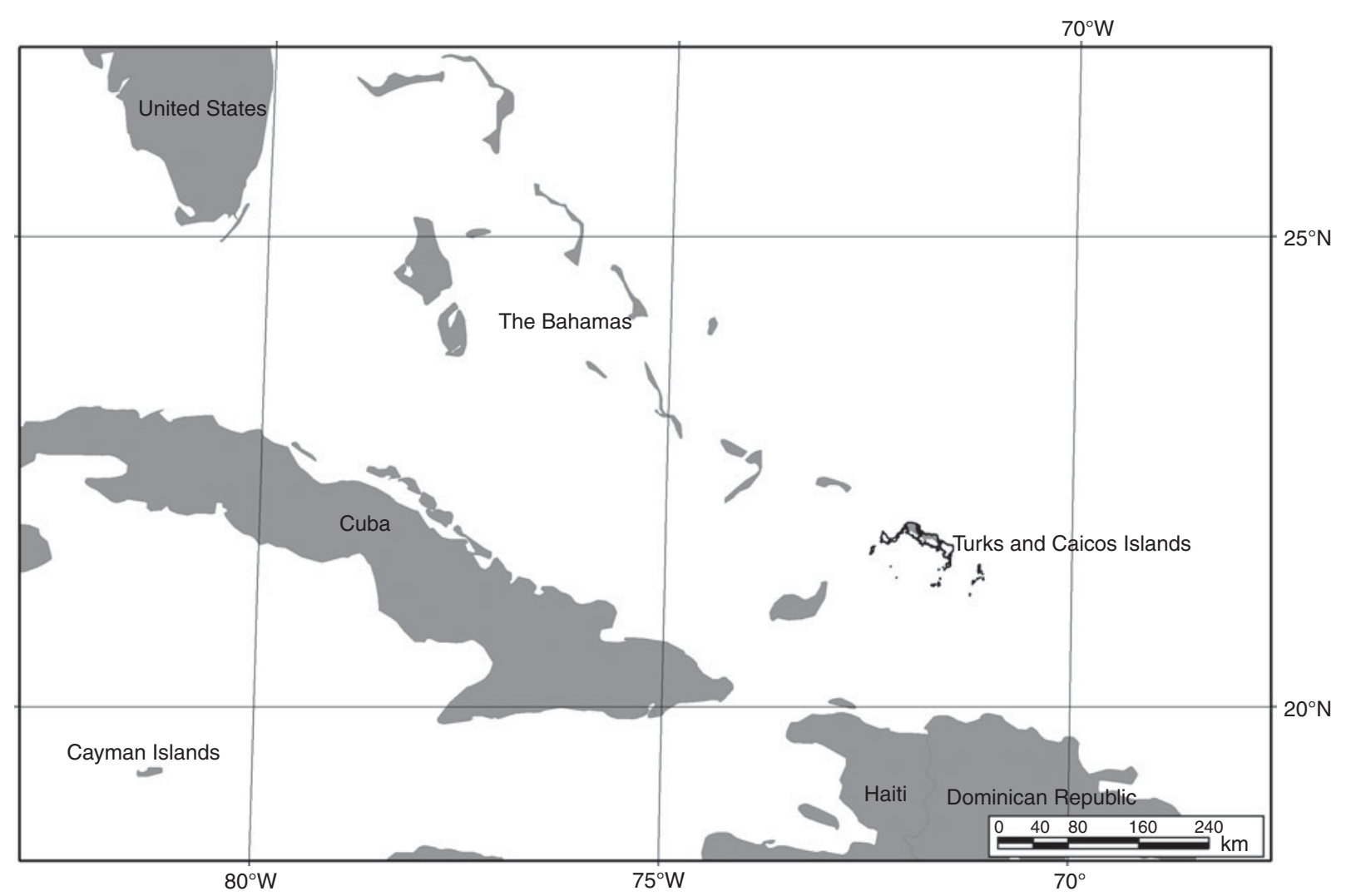

FIg. 1 The location of the Turks and Caicos Islands in the northern Caribbean. 
Hybrids with the non-endemic Encyclia altissima Schltr. occur. Pollination method is unknown. The seeds are wind dispersed.

Limonium bahamense (Griseb.) Britt. (Plumbaginaceae) is a small, herbaceous perennial up to $30 \mathrm{~cm}$ tall, restricted to salina habitats. As a juvenile the plant has a rosette of spatulate leaves close to the ground (Correll \& Correll, 1982). These are lost when the plant reaches maturity and forms a branched, leafless form with a green-grey photosynthetic succulent stem. The flowers form dense clusters, aggregated on one side of the spike (Correll \& Correll, 1982). A small blue butterfly (possibly Brephidium sp.) has been seen around the flowers and may be a pollinator. The species is probably insect pollinated, with wind dispersed seeds but this has not been verified (BNM, pers. obs.).

\section{Methods}

Fieldwork was carried out between 11 May and 27 June 2009. The distribution of the three endemic species and C. equisetifolia was assessed by recording presence and absence along 400-m transects, with assessment points every $50 \mathrm{~m}$. This survey strategy was designed to avoid spatial autocorrelation and represent all habitat types across the Islands (Sutherland, 2006). A hand-held computer with integrated global positioning system was used to record data directly into ArcPad v. 7.o (ESRI, Redlands, USA). In total 81 transects were surveyed across nine islands, two of which are uninhabited by humans. Middle and North Caicos were sampled more intensively than the other islands because of ease of accessibility but at least six transects were surveyed on each island. Detection error is highly unlikely for C. equisetifolia, E. caicensis and L. bahamense because of their distinct habit and form. However, detection error could bias results for $A$. argentea because of its discrete presence in the forest undergrowth, and therefore the strip width of each transect was only $2 \mathrm{~m}$. Observations of the plant recorded opportunistically off transects were also recorded. To assess the Red List status (IUCN, 2001) of the endemic species the extent of occurrence (the area contained within the shortest continuous imaginary boundary that can be drawn to encompass all the known sites of occurrence of a taxon, excluding cases of vagrancy) and area of occupancy (the area within the extent of occurrence that is occupied by a taxon) were calculated using Moat (2007).

Although niche-based models for C. equisetifolia could have been built using data from either the invaded range on the Turks and Caicos Islands or the native range (e.g. Australasia) we used the former. C. equisetifolia invaded the Islands c. 100 years ago and it is likely that its ecology is now different from in its native range. Factors specific to habitats within the Turks and Caicos Islands are now likely to be important in predicting suitable habitat for the species. If
TABLE 1 Environmental variables used in MaxEnt models for predicting habitat suitability for Casuarina equisetifolia, Argythamnia argentea, Encyclia caicensis and Limonium bahamense, with the data source and the date it was collected.

\begin{tabular}{|c|c|}
\hline Variable & Source \& date information was collected \\
\hline $\begin{array}{l}\text { Distance to nearest } \\
\text { north coast }\end{array}$ & \multirow{6}{*}{$\begin{array}{l}\text { Google Earth digitization \& ArcMap } \\
\text { calculations from Google Earth images } \\
\text { taken in } 2004 \text { \& 2006, accessed July } \\
2009\end{array}$} \\
\hline $\begin{array}{l}\text { Distance to nearest } \\
\text { south coast }\end{array}$ & \\
\hline $\begin{array}{l}\text { Distance to nearest } \\
\text { west coast }\end{array}$ & \\
\hline $\begin{array}{l}\text { Distance to nearest } \\
\text { east coast }\end{array}$ & \\
\hline $\begin{array}{l}\text { Distance to nearest } \\
\text { road }\end{array}$ & \\
\hline $\begin{array}{l}\text { Distance to nearest } \\
\text { settlement }\end{array}$ & \\
\hline Elevation & $\begin{array}{l}\text { Digital elevation model (ERSDAC, } \\
\text { 2009); data collected between } 2000 \text { \& } \\
\text { 2009, accessed August } 2009\end{array}$ \\
\hline $\begin{array}{l}\text { NDVI (Normalized } \\
\text { Difference Vegetation } \\
\text { Index) }\end{array}$ & $\begin{array}{l}\text { Landsat ETM+ of } 14 \text { December 2001, } \\
\text { accessed July } 2009\end{array}$ \\
\hline $\begin{array}{l}\text { Soil index (raw } \\
\text { thermal IR Band 6) }\end{array}$ & $\begin{array}{l}\text { Landsat ETM+ of } 14 \text { December 2001, } \\
\text { accessed July } 2009\end{array}$ \\
\hline
\end{tabular}

C. equisetifolia does not yet occupy all suitable environments in the Islands, the models may under-predict the full potential for invasion (Broennimann \& Guisan, 2008).

Maps of habitat predicted to be suitable for C. equisetifolia and the three endemic species were produced using habitat suitability models created with MaxEnt v. 3.3.1 (Phillips et al., 2006). Nine environmental predictors were used (Table 1). Distance to roads, coast and settlements were expected to be important predictor variables and were used to calibrate the models. The coastline was divided into north, south, east and west to assess the individual impact of each coastal aspect upon presence. Elevation, Normalized Difference Vegetation Index and soil index were included as environmental predictors because they are currently the only remotely sensed data available for the Islands. The island area was divided into a grid of cells of $30 \times 30 \mathrm{~m}$ and the model was used to calculate a probability of the presence of each species in each cell. Points that fell within the same grid cell were deleted before analysis to avoid overrepresentation in the model. Model outputs were interpreted with caution as some areas (e.g. near roads) were sampled more than others.

A random $75 \%$ of the presence points were used to develop each model; the remaining $25 \%$ were used to test model performance. The final model was chosen using the highest AUC (area under the receiver operating curve; Elith et al., 2006). A convergence threshold of 0.00001 with a maximum of 500 iterations and a maximum of 10,000 background points was used. Cross-validation involved four 
replicates, with each $25 \%$ of the presence points being used in turn for evaluation. Binary maps were created using minimum training thresholds in MaxEnt (C. equisetifolia: 0.036; A. argentea, 0.376; E. caicensis, 0.077; L. bahamense, $0.090)$.

Models can be compared using AUC values. AUC represents the chance that a randomly chosen presence point ranks as more suitable habitat than a random background point. It is calculated using pseudo-absences generated by randomly sampling the background grids rather than using true absence points. The area over which pseudo-absence points are chosen affects model performance and variable importance (VanDerWal, 2009; Elith et al., 2010). Pseudo-absence points were chosen over the whole archipelago for which predictor variables were available. This implies that the entire region was available to the species and to those collecting survey records. An alternative approach to background sampling is to develop a mask for indicating how far the species could have reached if conditions were suitable for its survival (Elith et al., 2010). However, a mask of reachable areas could not be created for the Islands because data on the historical rate of invasion were not available. Being a relatively small land mass compared to that used in Elith et al. (2010), Australia, this seems less of an issue because most areas are likely to be reachable.

To quantify the relationship between C. equisetifolia and native vegetation a paired plot design was used. A $10 \times 10 \mathrm{~m}$ plot invaded by $C$. equisetifolia and an adjacent plot uninvaded by $C$. equisetifolia were surveyed. Plots were paired to be as similar as possible in aspect, geology, habitat type and distance to sea and roads. Plots were classified as heavily disturbed, partially disturbed or intact according to the level of anthropogenic disturbance. Thirty pairs of plots were surveyed across Middle and North Caicos in a range of habitat and disturbance types. All plant species rooted in the plot were identified to species. The number of native species, as listed by Correll \& Correll (1982), was compared between plots using a matched pairs $t$-test with a significance threshold of $\mathrm{P}<0.05$. A log-linear model on nonorthogonal count data with Poisson errors was used to test the influence of $C$. equisetifolia invasion (present, absent), disturbance (high, partial or intact), habitat type (dune scrub, dune thicket, limestone scrub or limestone thicket), and all potential interactions between these factors, on native species richness. The model was checked for over-dispersion and simplified using a stepwise method (Crawley, 2007). Analysis was carried out using $R$ v. 2.9.2 (R Development Core Team, 2009).

\section{Results}

The endemic species were rare across the nine surveyed islands. A. argentea was located on five of the 81 transects, on three of the nine islands. E. caicensis was the most frequently encountered of the three species, detected on 10 transects but only on two islands. L. bahamense was located on eight transects across five islands. Including opportunistic presence records the total number of occurrences for each species were 53 for A. argentea, 142 for E. caicensis and 182 for L. bahamense. Using the IUCN Red List criteria (IUCN, 2001) the presence data resulted in all three species being categorized as Endangered. The extent of occurrence and area of occupancy for the three species met Criterion $\mathrm{B}$ with sub criterion a (fragmented populations) and $\mathrm{b}$ iii (declining area and quality of habitat).

Performance of the MaxEnt habitat suitability models was high, with test and training AUC values well over the 0.75 threshold above which models are considered useful (Elith, 2002). Presence records used in MaxEnt are shown in Fig. $2 \mathrm{a} \& \mathrm{~b}$. The MaxEnt model showed distance to roads to be the most important factor influencing distribution of C. equisetifolia, with presence being more likely closer to a road. The three endemic species exhibited a higher likelihood of presence closer to the east coast and further from roads. Fig. 3 illustrates the six islands, of the nine surveyed, which have overlap between predicted suitable habitat for $C$. equisetifolia and for the three endemic species. All islands were predicted to have suitable habitat for C. equisetifolia. Our field observations show that C. equisetifolia has colonized all islands except Big Ambergris Cay.

None of the three endemic species were found growing under C. equisetifolia. Plant species richness in plots invaded by $C$. equisetifolia was significantly lower than that of uninvaded plots (Fig. 4; paired t-test with equal variances, $t=5.08, \mathrm{df}=29, \mathrm{P}<0.05)$. Of the 77 species recorded in plots, 26 were never found under C. equisetifolia, suggesting they may grow poorly or not at all in the presence of this invasive tree.

Whether a plot was invaded or uninvaded by C. equisetifolia was the only significant factor that explained native species richness (log-linear model with Poisson errors on non-orthogonal count data, $\mathrm{n}=60$, intercept $=2.21$, $\mathrm{P}<0.01$, Uninvaded plot $\mathrm{vs}$ invaded plot coefficient $=$ $-0.44, \mathrm{P}<0.01)$. No interaction terms were significant. Habitat type was removed from the model because it caused an insignificant increase in residual deviance $\left(\chi^{2}, \mathrm{df}=3\right.$, $\mathrm{P}=0.95)$ and disturbance level was removed for the same reason $\left(\chi^{2}, \mathrm{df}=2, \mathrm{P}=0.08\right)$ and this improved the fit of the model.

\section{Discussion}

The data from this presence/absence survey show that the three endemic species examined have very restricted ranges on the Turks and Caicos Islands and should be categorized as Endangered on the IUCN Red List. Although we aimed to 


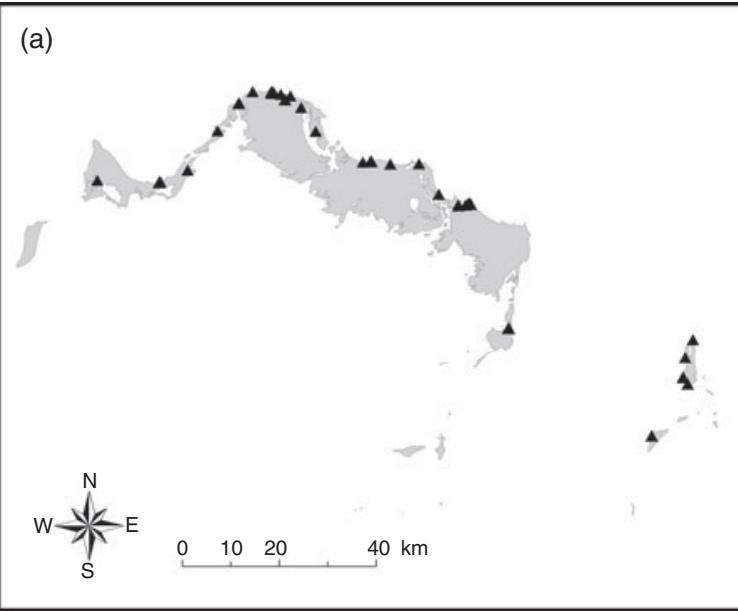

(b)
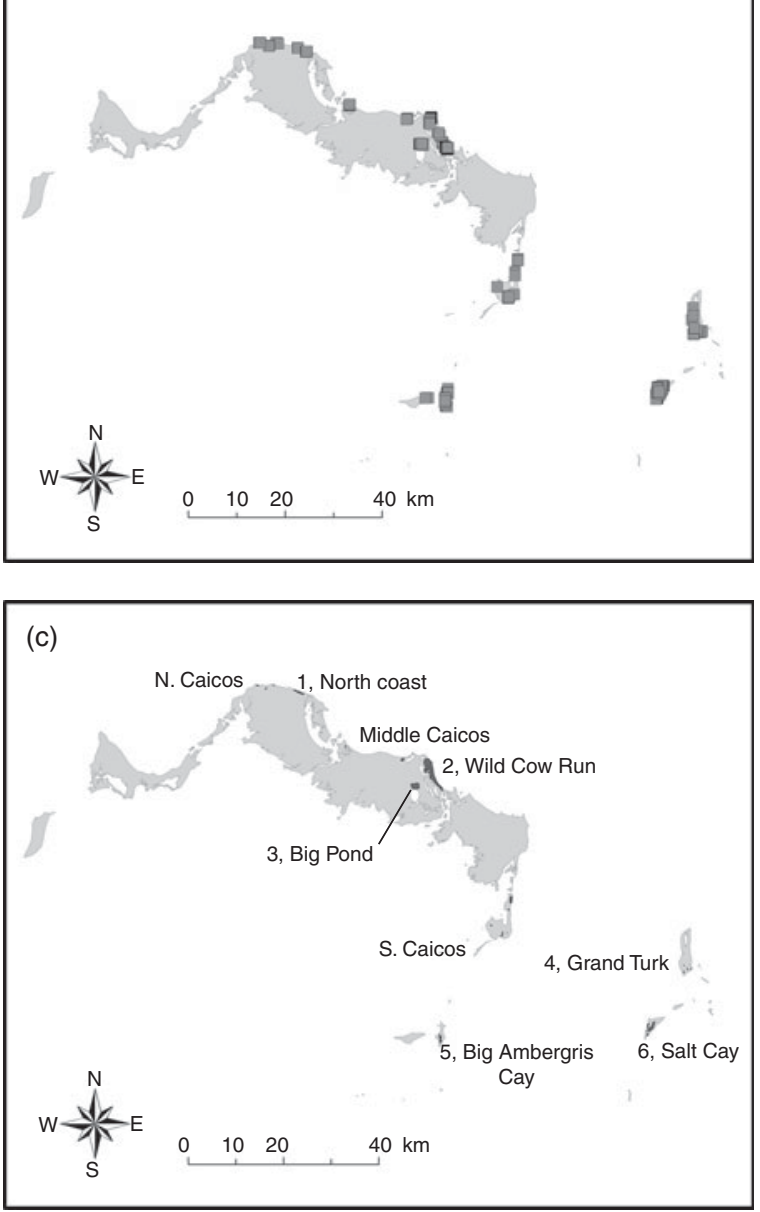

FIg. 2 (a) Presence records for the invasive tree Casuarina equisetifolia observed during field surveys in the Turks and Caicos Islands. (b) Presence records for the endemic species Argythamnia argentea, Encyclia caicensis and Limonium bahamense. (c) Important Plant Areas proposed: 1, North coast (North Caicos); 2, Wild Cow Run (Middle Caicos); 3, Big Pond (Middle Caicos); 4, Grand Turk; 5, Big Ambergris Cay; 6, Salt Cay.

reduce bias by surveying all habitats and across as many islands as possible it was not possible to sample randomly because large areas are inaccessible; the influence of distance to roads may be inflated by this bias. Model predictions could be improved by methods that collect occurrence records from the full range of habitats inhabited by the species (Phillips et al., 2006; Gaston \& Fuller, 2009). For example, the lack of predicted suitable habitat for the endemic plants on the uninhabited island of East Caicos may represent under-sampling and an absence of roads. Improved coverage of survey points along environmental and geographical gradients would improve the models (Hortal et al., 2008).

Distribution maps of invasive species have been criticized as misleading because they rely on coarse data and do not reflect the complexity of dispersal patterns (Hulme, 2003). Nevertheless, our maps provide a useful general indication of where the three endemic species are likely to be threatened by the invasive $C$. equisetifolia. The strength of these maps lies in the matched methods used to survey and analyse the ranges of the endemic and invasive plant species, making them directly comparable. Large areas are suitable for both C. equisetifolia and the three endemics. C. equisetifolia is associated with reduced native species diversity in its vicinity and no endemic plants were found growing beneath it. This evidence suggests that C. equisetifolia is a significant threat to the survival of the three endemics.

The presence of C. equisetifolia was the only significant variable in explaining variation in native plant species richness between invaded and uninvaded plots, whereas disturbance and habitat type were not significant factors. This indicates that the presence of C. equisetifolia reduces plant species richness, rather than the reduction being due to invaded plots being disturbed areas. Nevertheless, disturbance, particularly the building of roads, appears to facilitate C. equisetifolia invasion, with this being the most important factor in the predictive mapping of suitable habitat. C. equisetifolia seeds can be dispersed by both wind and motor vehicle tyres and thus roads are a pathway of accelerated dispersal. Road building should be carried out in a sensitive way to minimize the spread and impact of exotic plants. This could be through targeting road building towards more resistant or already degraded community types or re-establishing native vegetation after construction (Gelbard \& Belnap, 2003).

Many invasive plants colonize disturbed areas faster than intact habitats (Meyerson \& Mooney, 2007). This has led to a debate regarding whether it is the habitat change or the invasive species driving the impact on native species. MacDougall \& Turkington (2005) articulate this debate in terms of the driver and passenger models. In the driver model, exotic species outcompete native species through a direct interaction. In the passenger model, non-interactive factors, such as habitat disturbance, favour dominant species. In an examination of exotic grasses in an oak savannah MacDougall \& Turkington (2005) found evidence 


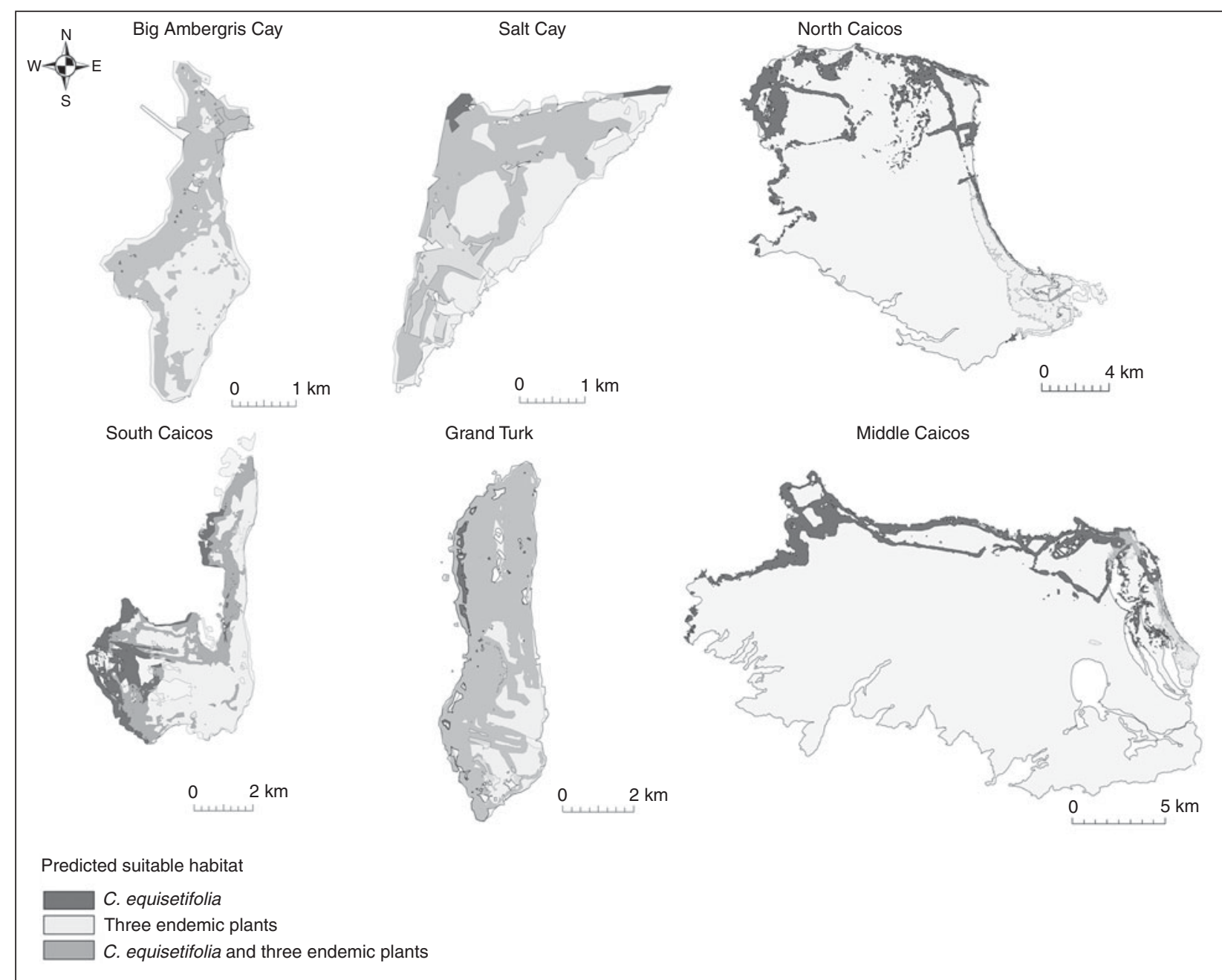

Fig. 3 The extent of overlap in predicted suitable habitat for the endemic plants A. argentea, L. bahamense and E. caicensis and the invasive tree C. equisetifolia on six of the nine surveyed islands. The light grey areas are predicted to be suitable habitat for the endemic plants but not for C. equisetifolia and thus are areas of priority for future conservation work.

for the passenger model. However driver and passenger models are extremes of a continuum and an ecosystem is likely to lie between the two extremes (Didham et al., 2005). Our study suggests that $C$. equisetifolia is more of a driver than a passenger.

The dense mat of pine-needle-like leaves and branchlets that we observed under C. equisetifolia could be a mechanism by which the species causes reduced native species richness. Litter fall is thought to suppress recruitment of native species (Gordon, 1998) and there is evidence of the allelopathic nature of leaves of C. equisetifolia on crop species (Jadhav \& Gaynar, 1995), probably due to high concentrations of selenium and salts and low decomposition rates (Parrotta, 1993). The shade created by C. equisetifolia may put dune species adapted to high light levels at a disadvantage (Marchante et al., 2003). Being a nitrogen-fixing species C. equisetifolia is also likely to alter local nutrient cycling, perhaps changing the ecological niches of native species (Gordon, 1998). These factors could explain the negative effects of C. equisetifolia on native species. A removal experiment (e.g. Gould \& Gorchov, 2000) could be used to test this.

Most of the overlap in suitable habitat for both C. equisetifolia and the three endemic species, especially A. argentea and L. bahamense, is on the islands of Big Ambergris Cay, Grand Turk and Salt Cay. The distribution of the three endemic species is very limited and the synergistic threats of invasive plants and development threaten to reduce their range further. Conservation efforts to help retain these rare plants in the ecosystem are a priority, and protecting the habitats of such rare species could also help control the spread of invasive species. Experimental removal of rare species in an assemblage resulted in higher colonization by an exotic grass than controls (Lyons \& Schwartz, 2001). Conservation planning for rare plants therefore needs a combined approach of both habitat protection and invasion control. 


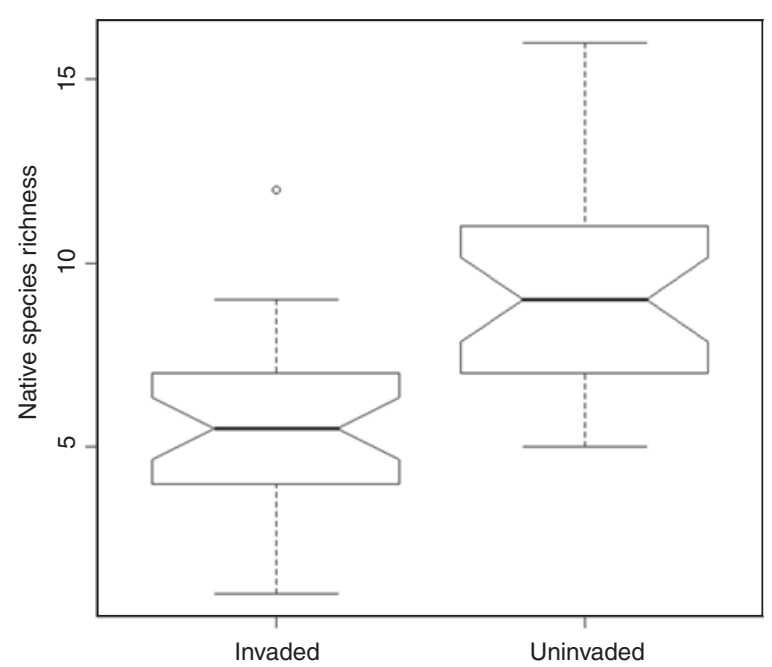

FIG. 4 Box plot of richness of native plant species in plots invaded and uninvaded by C. equisetifolia. The boxes show the middle $50 \%$ of data around the median. The whiskers for the invaded plot show 1.5 times the interquartile range and one outlier, the whiskers for the uninvaded plot show the maximum and minimum values. The notches give an approximate $95 \%$ confidence interval for the difference between the medians. In this case the notches do not overlap, illustrating the medians are significantly different, as shown by a paired $t$-test (see text for details).

The identification of key sites, as yet uninvaded by C. equisetifolia, as IPAs would provide international recognition of the botanical importance of these areas. Based on our observations of where the endemic plants occur (Fig. 2b), along with predictions of areas suitable for C. equisetifolia invasion (Fig. 3), we identified six potential IPAs: the north coast of North Caicos, Wild Cow Run and Big Pond on Middle Caicos, and parts of Grand Turk, Big Ambergris Cay and Salt Cay (Fig. 2c). Although identification of an area as an IPA does not provide any legal protection, IPA status highlights the need to conserve a site. The proposed IPA sites on Big Ambergris Cay, Middle Caicos and Salt Cay are all areas marked for development. With careful planning the impact of these developments could be minimized to ensure that the populations of endemic species are not detrimentally affected, for example by avoiding facilitation of invasion by C. equisetifolia.

Target 8 of the the Global Strategy for Plant Conservation is to have $60 \%$ of threatened plant species in ex situ collections and $10 \%$ of these in restoration or recovery programmes. All three endemic species studied here are held in the Government nursery on North Caicos and seeds are stored in the Millennium Seed Bank of the Royal Botanic Gardens (RBG), Kew, UK. In addition ex situ collections of L. bahamense and E. caicensis are held at RBG. Genetic material from the wild populations of the three endemic plant species has been collected for addition to the RBG DNA Bank. Future research will evaluate the population genetics of these species in the wild and the representativeness of the ex situ collections. The next step is to develop action plans for each species to guide conservation action and ensure their long-term survival.

Preventing invasion of uninvaded areas that are key sites for the three endemic species (IPAs in particular) can now be prioritized using the maps in Fig. 3. In Florida, C. equisetifolia control focuses on attacking nascent foci (newly established colonies) to contain the invader, as total eradication is infeasible (Mack \& Lonsdale, 2002). Biological control could be an option for control of C. equisetifolia (Pemberton, 1996) and the costs and benefits of various foliage-feeding insects are being evaluated (CSIRO, 2010). Mechanical control is currently the best option. It has been a successful control strategy (Simberloff, 2009) and used to create new employment opportunities (Foxcroft \& FreitagRonaldson, 2007). One disadvantage of mechanical control is the high recurring cost.

Conservation of the six IPAs that we have identified would be a valuable step towards ensuring the survival of the three endemic species. This study provides the basis for formal identification of the proposed IPAs, which we hope will take place when the political situation allows. Our results and recommendations have been presented in the Turks and Caicos Islands at both a public meeting and to the Government Department of Environment and Coastal Resources. The Turks and Caicos Islands Environmental Club has begun an invasive plant identification and training programme, and is involved in some removal. The Turks and Caicos Islands government is considering a programme to encourage the harvesting of $C$. equisetifolia for charcoal production. This could help control the species, limiting the seed set potential through coppicing, and provide local livelihoods. However, the programme would need to be monitored to ensure that the harvesting does not encourage expansion of C. equisetifolia. A programme that combines harvesting for charcoal production, control of the invading frontier and removal of outliers in the population would be a major contribution to Target 10 of the Global Strategy for Plant Conservation. Research is now being carried out to ground truth the outputs of the predictive habitat mapping presented here and investigate social attitudes towards using C. equisetifolia rather than native trees as a source of charcoal. C. equisetifolia is a serious threat to the native flora of the Turks and Caicos Islands and the results of this study are helping to focus research and control efforts.

\section{Acknowledgements}

We would like to thank Dr Colin Clubbe (RBG, Kew), Marcella Corcoran (RBG, Kew), Miranda Jones (TCNT) and Bob McMeekin (TCNT) for their help and enthusiasm. Many thanks to the Royal Botanic Gardens, Kew, Imperial College London, The Turks and Caicos National Trust, 
the Turks and Caicos Department of Environment and Coastal Resources for support and collaboration on this project. Thanks to the Oleg Polunin Memorial Fund, Hilda Martindale Trust, Reid Trust, the Mercers Company, the Overseas Territories Environment Programme and the Studley College Trust for additional financial support. Thanks to E.J. Milner-Gulland, Dave Roberts and two anonymous reviewers for useful comments on the first draft.

\section{References}

Broennimann, O. \& Guisan, A. (2008) Predicting current and future biological invasions: both native and invaded ranges matter. Biology Letters, 4, 585-589.

Correll, D.S. \& Correll, H.B. (1982) Flora of the Bahama Archipelago: Including the Turks and Caicos Islands. A.R.G. Gantner Verlag, Vaduz, Liechtenstein.

Crawley, M. (2007) The R Book. John Wiley, Chichester, UK.

CSIRO Commonwealth Scientific and Industrial Research Organisation (2010) Biological control of Australian native Casuarina species in the USA. Http://www.csiro.au/science/ps334. html [accessed September 2010].

Didham, R.K., Tylianakis, J.M., Hutchison, M.A., Ewers, R.M. \& Gemmell, N.J. (2005) Are invasive species the drivers of ecological change? Trends in Ecology \& Evolution, 20, 470-474.

Elfers, S.C.I. (1988) Element Stewardship Abstract for Casuarina equisetifolia. The Nature Conservancy, Arlington, USA.

Elith, J. (2002) Quantitative methods for modeling species habitat: comparative performance and an application to Australian plants. In Quantitative Methods for Conservation Biology (eds S. Ferson \& M. Burgman), pp. 39-58. Springer-Verlag, New York, USA.

Elith, J., Graham, C.H., Anderson, R.P., Dud'k, M., Ferrier, S., Guisan, A. et al. (2006) Novel methods improve prediction of species' distributions from occurrence data. Ecography, 29, 129-151.

Elith, J., Kearney, M. \& Phillips, S. (2010) The art of modelling range-shifting species. Methods in Ecology and Evolution, 1, 330-342.

ERSDaC Earth Remote Sensing Data Analysis Center (2009) Http://www.ersdac.or.jp/GDEM/E/index.html [accessed July 2009].

Foxcroft, L.C. \& Freitag-Ronaldson, S. (2007) Seven decades of institutional learning: managing alien plant invasions in the Kruger National Park, South Africa. Oryx, 41, 160-167.

Garland-Campbell, J. (2008) Environmental laws of the Turks \& Caicos Islands. In A History of the Turks \& Caicos Islands (ed. C. Mills), pp. 59-67. Macmillian Publishers Limited, Oxford, UK.

Gaston, K.J. \& Fuller, R.A. (2009) The sizes of species' geographic ranges. Journal of Applied Ecology, 46, 1-9.

Gelbard, J.L. \& Belnap, J. (2003) Roads as conduits for exotic plant invasions in a semiarid landscape. Conservation Biology, 17, 420-432.

GISD (2009) Global Invasive Species Database. Http://www.issg.org/ database [accessed 2 December 2011].

Gordon, D.R. (1998) Effects of invasive, non-indigenous plant species on ecosystem processes: lessons from Florida. Ecological Applications, 8, 975-989.

Gould, A.M. \& Gorchov, D.L. (2000) Effects of the exotic invasive shrub Lonicera maackii on the survival and fecundity of three species of native annuals. The American Midland Naturalist, 144, $36-50$.

Hardman, C.J. (2009) Invasive Plants in the Turks and Caicos Islands. Http://www.iccs.org.uk [accessed 14 December 2009].
Hortal, J., Jiménez-Valverde, A., Gomez, J.F., Lobo, J.M. \& BASELGA, A. (2008) Historical bias in biodiversity inventories affects the observed environmental niche of the species. Oikos, 117 , $847-858$.

Hulme, P.E. (2003) Biological invasions: winning the science battles but losing the conservation war? Oryx, 37, 178-193.

IUCN (2001) IUCN Red List Categories and Criteria: Version 3.1. IUCN Species Survival Commission, Gland, Switzerland.

JADHAV, B.B. \& GAYNAR, D.G. (1995) Effect of Casuarina equisetifolia leaf litter leachates on germination and seedling growth of rice and cowpea. Allelopathy Journal, 1, 105-108.

Kairo, M., Ali, B., Cheesman, O., Haysom, K. \& Murphy, S. (2003) Invasive Species Threats in the Caribbean Region. Report to the Nature Conservancy. CAB International, Curepe, Trinidad \& Tobago.

Langeland, K.A. \& Burks, K.C. (eds) (1998) Identification \& Biology of Non-Native Plants in Florida's Natural Areas. UF/IFAS, Gainesville, USA.

Lyons, G.K. \& Schwartz, M.W. (2001) Rare species loss alters ecosystem function-invasion resistance. Ecology Letters, 4, 358-365.

MacDougall, A.S. \& Turkington, R. (2005) Are invasive species the drivers or passengers of change in degraded ecosystems? Ecology, 86, 42-55.

MACK, R.N. \& LONSDALE, W.M. (2002) Eradicating invasive plants: hard-won lessons for islands. In Turning the tide: the eradication of invasive species. (C.R. Veitch \& M.N. Clout, eds), pp. 164-172. IUCN Species Survival Commission Invasive Species Specialist Group, Gland, Switzerland, and Cambridge, UK.

Marchante, H., Marchante, E. \& Freitas, H. (2003) Invasion of the Portuguese dune ecosystem by the exotic species Acacia longifolia (Andrews) Willd.: effects at the community level. In Plant Invasion: Ecological Threats and Management Solutions (eds L. Child, J.H. Brock, G. Brundu, K. Prach, P. Pysek, P.M. Wade \& M. Williamson), pp. 67-71. Backhuys Publishers, Leiden, The Netherlands.

Masterson, J. (2007) Report on Casuarina equisetifolia. Http:// www.sms.si.edu/irlspec/Casuarina_equisetifolia.htm [accessed 2 December 2011].

Meyerson, L. A. \& Mooney, H. A. (2007) Frontiers in Ecology and the Environment, 5, 199-208.

Mills, C. (ed.) (2008) A History of the Turks \& Caicos Islands. Macmillan, Oxford, UK.

MoAт, J. (2007) Conservation Assessment Tools Extension for ArcView 3.x, v. 1.2. GIS Unit, Royal Botanic Gardens, Kew, UK. Http://www.kew.org/gis/projects/cats/catsdoc.pdf [accessed September 2009].

Myers, N., Mittermeier, R.A., Mittermeier, C.G., DA Fonseca, G.A.B. \& Kent, J. (2000) Biodiversity hotspots for conservation priorities. Nature, 403, 853-858.

Parrotta, J.A. (1993) Casuarina equisetifolia. USDA Forest Services International Institute of Tropical Forestry, Río Piedras, Puerto Rico. Http://www.fs.fed.us/global/iitf/pubs/sm_iitfo56\%20\%20(11). pdf [accessed 2 December 2011].

Pemberton, R.W. (1996) The potential of biological control for the suppression of invasive weeds of southern environments. Castanea, 61, 313-319.

Phillips, S.J., Anderson, R.P. \& Schapire, R.E. (2006) Maximum entropy modelling of species geographic distributions. Ecological modelling, 190, 231-259.

Plantlife International (2006) CBD Global Strategy for Plant Conservation Update on Progress for Target 5. Http://www.plantlife. org.uk/international/plantlife-ipas-regional-global.htm [accessed 18 July 2009]. 
Ray, G.C. \& Bolten, A. (coord.) (1999) The Commonwealth of the Bahamas. National Biodiversity Strategy and Action Plan. Report to UNEP. Http://www.cbd.int/doc/world/bs/bs-nb-01-en.pdf [accessed 25 January 2010]

R Development Core Team (2009) R: A Language and Environment for Statistical Computing. R Foundation for Statistical Computing, Vienna, Austria. Http://www.R-project.org [accessed March 2009].

Secretariat of the CBD (Convention on Biological Diversity) (2010) The Global Strategy for Plant Conservation. Http://www.cbd.int/doc/meetings/cop/cop-10/official/cop-10-19-en. pdf [accessed 20 January 2010].

Simberloff, D. (2009) We can eliminate invasions or live with them. Successful management projects. Biological Invasions, 11, 149-157.

Sutherland, W. (ed.) (2006) Ecological Census Techniques: A Handbook, and edition. Cambridge University Press, Cambridge, UK.

VanDerWal, J., Shoo, L.P., Graham, C. \& Williams, S. E. (2009) Selecting pseudo-absence data for presence-only distribution modelling: how far should you stray from what you know?

Ecological Modelling, 220, 589-594.

Weber, E. (2003) Invasive Plant Species of the World: A Reference Guide to Environmental Weeds. CABI publishing, Wallingford, UK.

\section{Biographical sketches}

CHLOe J. HARDMAN is interested in ecological research that informs conservation action, particularly ecological interactions, invasive species and spatial analysis. SoPHIE W ILLIA Ms has research interests in the conservation of wild harvested plant species. BRYAN NAQQI MANCO is interested in all aspects of the terrestrial flora and fauna of the Turks and Caicos Islands and works for the Turks and Caicos Islands Department of Environment and Coastal Resources. MARTIN Hamilton is the UK Overseas Territories Programme Co-ordinator at the Royal Botanic Gardens, Kew. He is particularly interested in the conservation of the threatened plant species of UK Overseas Territories. 